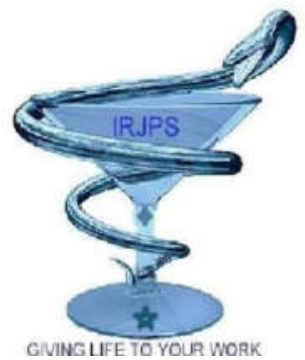

\title{
EFFECT OF VARIOUS SHADING LEVELS ON GROWTH OF SEEDLINGS OF EGGPLANT (SOLANUM MELONGENA L.) UNDER GREENHOUSE CONDITIONIN THE TROPICAL REGION.
}

\author{
KutaibaYuserAied $^{* 1,2}{ }^{\text {, ZakariaWahab }}{ }^{3}$,Rezuwan.Hj. Kamaruddin ${ }^{2}$, AbdRazakShaari $^{3}$
}

${ }^{1}$ Department of Horticulture, College of Agriculture, University of Tikrit, Salah Al-deen, Iraq.

${ }^{2}$ School of Bioprocess Engineering, University Malaysia Perlis, Jejawi 3, 02600 Arau, Perlis, Malaysia.

${ }^{3}$ Faculty of Engineering Technology, University Malaysia Perlis, 02100 Padang Besar, Unicity Campus.

Submitted on: 07.02.16;

Revised on: 24.02.17;

Accepted on: 01.03 .17

\begin{abstract}
Eggplant (Solanum melongena L.) is one of the most important solanaceous crop. It is mainly used as a vegetable. It naturally propagates via seeds, however, some seeds are sensitive to light and susceptible to germination.The quality of the seedling is very important,as it affects the subsequent well-being of theplant.This study aims to improve eggplant seedling production by manipulating the shade levels of the greenhouse (control[without shade], 30\% shade, 50\% shade, and 70\% shade). The experimental design usedwas a factorial experiment (with randomized complete block design) in nine replicates for germination percentage and germination time, and four replicatesfor other seedling.

The results indicated that the shade treatments had no significant effect on germination,instead, they significantly affected the total leaf area, leaf number, seedling height and seedling weight, all of which are directly proportional to the shade levels.However, shade levels and chlorophyll content, stem diameter and the percentage of dry matter were inversely related to shade levels. The findings confirmed that shade treatments results in anoptimal condition for eggplant seedling productionin a greenhouse in the tropical regions.
\end{abstract}

KEYWORDS: Shading, Seedlings, Greenhouse, Eggplant.

Corresponding Author: Kutaiba Yuser Aied E-mail: qu_802000@yahoo.com
Indian Research Journal of Pharmacy and Science; 12(2017) 876-886 Journal Home Page: https://www.irjps.in 


\section{INTRODUCTION}

Vegetables are important for human health as they contain nutrients such as vitamins, minerals, proteins, fibers, and bio-functional components.Malays preferred traditional vegetables,such as eggplants (Solanum melongena L. ${ }^{[12]}$.The eggplant is one of the most important solanaceous crops, and is mainly consumed as food or used in traditional medicines.Its tissue extracts have been used to treat asthma, bronchitis, cholera, and dysuria, while its fruits and leaves help lower blood cholesterol. It is a good source of vitamins and minerals especially iron. It is therefore regarded as an important vegetable crop in tropical and temperate regions of the world.

Abiotic stresses can be observed on plants via its physiological status and itsdirect or indirect effect on its metabolism, development, leaf growth, and chlorophyll content. Protected cultivation could help decrease biotic and abiotic stresses.Greenhouses provide better growth conditions $^{[3]}$.

The use of porous screens for covering agricultural crops is fast increasing. Light is an important environmental factor for plantsdue to its role in photosynthesis andthe development of leaves. Although light is a requirement for plant growth and development, different plants have different optimal light requirements, aseither deficient or excessive light intensities might injure plants ${ }^{[2]}$. Also, ${ }^{[17]}$ pointed out that there is an optimal light intensity for each crop species that maximizes photosynthesis and plant growth. ${ }^{[4]}$ reportedthat the seeds of certain species are sensitive to light in the context of inducing germination, while ${ }^{[9]}$ mentioned that light irradiation is an important regulator of seed germination in solanaceous crops. ${ }^{[14]}$ foundthat light irradiation is highly effective for eggplant seed germination. However, ${ }^{[10]}$ said that seedlings should not be fully exposed to direct sunlight because they might be developmentally stunted compared to seedlings being shaded. Seedling quality is very important due to its subsequenteffect on plant performance.The productivity of vegetables can be increased,therefore, this study intends to determine the optimal shade level for producing eggplant seedlings in a greenhouse in a tropical region.

\section{MATERIALS AND METHODS}

\subsection{Experimental design:}

The experimental design used was a factorial experiment with randomized complete block in nine replicates for germination percentage and germination time and four replicatesfor other characteristics. Duncan's test was used to evaluate differences between the means. Significance was reported at $\mathrm{P}<0.05$ using the SAS version $9.2^{[15]}$.

\subsection{Seeds and growing conditions:}

The experiment was carried out at the Institute of Sustainable Agrotechnologyfield, University Malaysia Perlis (UniMAP), Padang Besar, Perlis, Malaysia.Eggplant (Solanum melongena L.)seeds used in the experiment was purple long variety type (F1hybrid), procured from the Green World Co.The seeds were germinated on aplastic tray (105-hole size).

\subsection{Treatments:}

The experiment was carried out using three levels of shade $(30 \%, 50 \%$, and $70 \%)$, as per information reported byJiahua Hardware Wire mesh Co.,Ltd. China.Light intensity, temperature and humidity were measured under each treatment, in addition to control, as per Table 1 .

Table 1 Light intensity, temperature and relative humidity under shading level treatments.

\begin{tabular}{|c|c|c|c|c|}
\hline \multirow{2}{*}{ Measurement } & \multicolumn{4}{|c|}{ Shading levels } \\
\cline { 2 - 5 } & Control & $30 \%$ shade & $50 \%$ shade & $70 \%$ shade \\
\hline Light intensity (Lux) & 73250 & 49550 & 37750 & 24500 \\
\hline Temperature $\left({ }^{\circ} \mathrm{C}\right)$ & 34.42 & 34.29 & 34.26 & 34.25 \\
\hline Relativehumidity $(\%)$ & 80.70 & 77.28 & 75.47 & 76.75 \\
\hline
\end{tabular}

\subsection{Parameters}

The seeds were planted in plastic trays (Size 105 hole).Nine replicates were used to measure percentage of germination and germination speed (days to germination)and four replicates for other characteristics.

\subsubsection{Percentage of Germination:}

Germination $\%=\frac{\text { Number of germinated seeds }}{\text { Total number of seeds }} \times 100^{[5]}$ 


\subsubsection{Mean germination time}

After planting the seeds, the mean germination time (MGT) was calculated by following seed germination every day, using the equation [5]:

$\mathrm{MGT}=(\mathrm{n} 1 \times \mathrm{d} 1)+(\mathrm{n} 2 \times \mathrm{d} 2)+(\mathrm{n} 3 \times \mathrm{d} 3)+-\cdot-\cdot-\cdot$ / Total number of days

Where, $n=$ number of germinated seed

$\mathrm{d}=$ number of days

\subsubsection{Measurement of chlorophyll content} After 30 days, the chlorophyll content was measured in four replicates for each treatment where each replicate has four seedlings using the SPAD device (KONICA MINOLTA).

\subsubsection{Wet weight of seedling}

After 30 days, the seedling was ready for transplanting.Four seedlings for each replicate were used to obtainthe mean seedling weight.

\subsubsection{Seedling dry matter percentage}

The seedlings werestored in paperbags. The sampleswere dried using the oven at $70^{\circ} \mathrm{C}$ until the weights were constant. The dried seedlingweight was determined using the following equation:

Percentage of seedlingdry matter $=\frac{\text { seedling dry weight }}{\text { seedling fresh weight }} \times 100$

\subsubsection{Height of seedling}

The measurement was done using a measuring tape to measure the height of four seedlings for each replicate, with the average taken for further analyses.

\subsubsection{Stem diameter}

A digital Vernier caliper was usedto measure the stem diameterand the average of four seedlings for each replicate was taken for further analyses.

\subsubsection{Number of leaves:}

The leaf number was countedfor four seedlings for each replicate,and the average was taken for further analyses.

\subsubsection{Total leaf area}

The leaf area meter was used to measurethe total leaf area of four seedlings for each replicate.

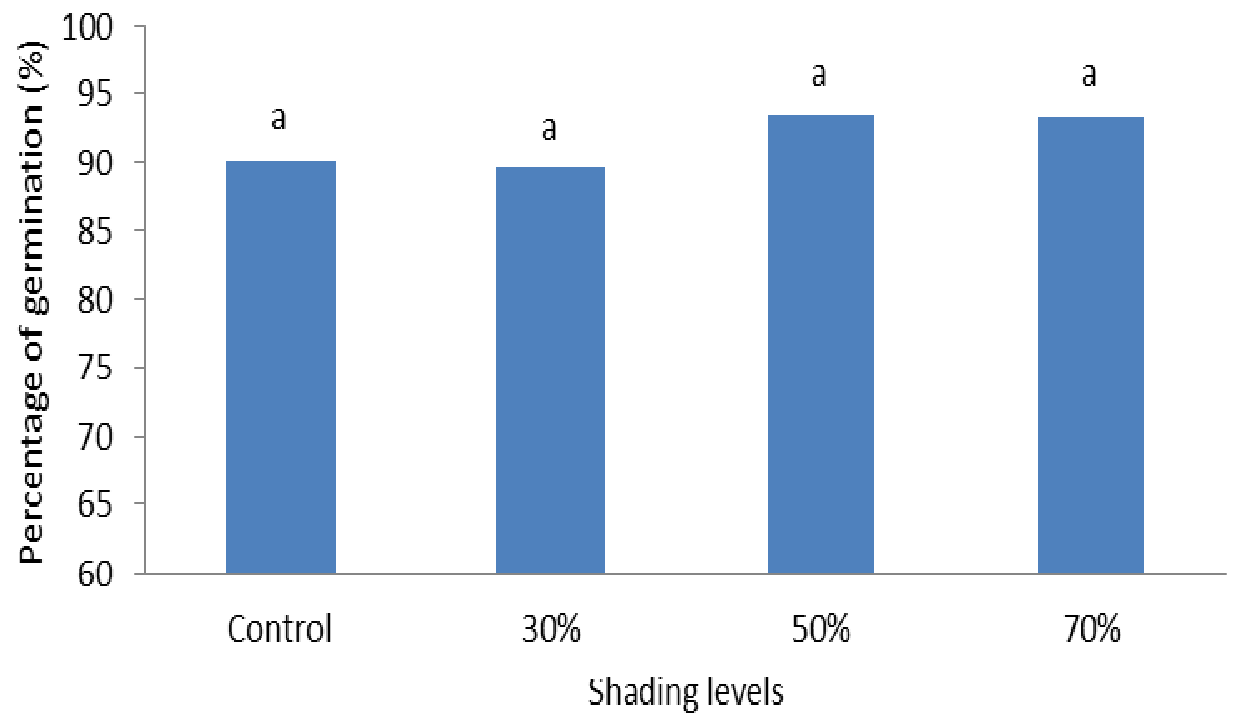

Fig.1. Percentage of germination as affected by different shading levels.

(Treatments with same letter are not significantly different according to Duncan test at $\mathrm{P} \leq 0.05$ ).

\section{RESULTS AND DISCUSSION}

According to the experimental results, the shading levels affected certain characteristics of the seedlings:

\subsection{Percentage of Germination}

Figure1 shows no significant effect among the treatments, although there was a slight increase in percentage of germination under $50 \%$ and $70 \%$ shading levels compared with $30 \%$ shading level and the control treatment.

3.2. Mean germination timeThe result showed no significant influence of shade treatments on the mean germination time (Figure 2). 


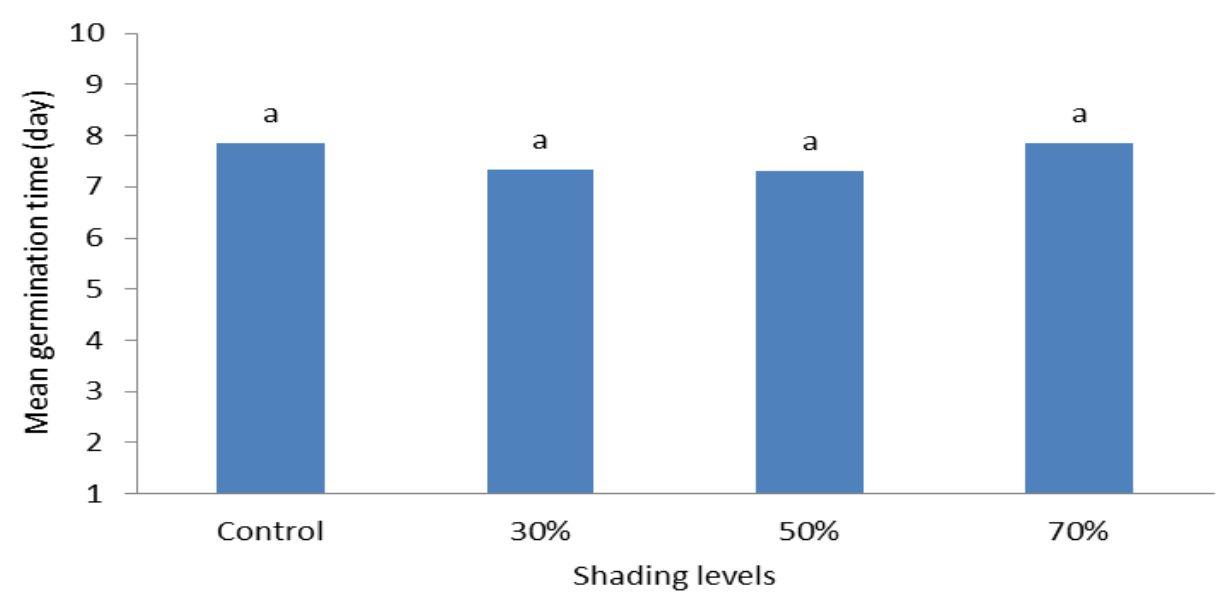

Fig.2. Mean germination time as affected by different shading levels.

(Treatments with same letter are not significantly different according to Duncan test at $\mathrm{P} \leq 0.05$ ).

\subsection{Total leaf area}

Shading level had a significant effect on the total leaf area.Table2showedan increment of total leaf area with increased shade level.There was a positive correlation $\left(\mathrm{R}^{2}=0.98\right)$ between shading level and total leaf area, as per Figure 3.
However, a bigger leaf area was $181.07 \mathrm{~cm}^{2}$ obtained from a $70 \%$ shading level, while the control treatment resulted in the smallest leaf area $\left(124.22 \mathrm{~cm}^{2}\right)$ as shown in Table 2.

Table 2 Total leaf area as affected by different shading levels and correlation coefficient with leaf number

\begin{tabular}{|lcccc|}
\hline \multicolumn{1}{|c}{ Shading levels } & Control & $\mathbf{3 0 \%}$ & $\mathbf{5 0 \%}$ & $\mathbf{7 0 \%}$ \\
\hline Total leaf area $\left(\mathrm{cm}^{2}\right)$ & $124.22 \mathrm{c}$ & $153.25 \mathrm{~b}$ & $168.6 \mathrm{ab}$ & $181.07 \mathrm{a}$ \\
\hline Leaf number & $4.12 \mathrm{~b}$ & $4.12 \mathrm{~b}$ & $4.18 \mathrm{ab}$ & $4.5 \mathrm{a}$ \\
\hline correlation coefficient $=0.74$ & & & & \\
\hline
\end{tabular}

(Treatments with same letter are not significantly different according to Duncan test at $\mathrm{P} \leq 0.05$ ).

Thisleaf area increment was as a result of increasing of leaf number in addition to individual leaf area increment, where there wasa positive correlation between leaf number and total leaf area, as perthe correlation coefficient $=0.74$, as shown in Table 2. This could be due to the fact that the plant tends to increase the leaf area when shadedto increase light assimilation. These results agree with the ones reported by ${ }^{[7],[18]}$ and ${ }^{[13]}$, but not with $^{[2]}$ whom found that low light intensity caused significant reduction in the leaf area of Dioscoreophyllumcumminsiiseedling.

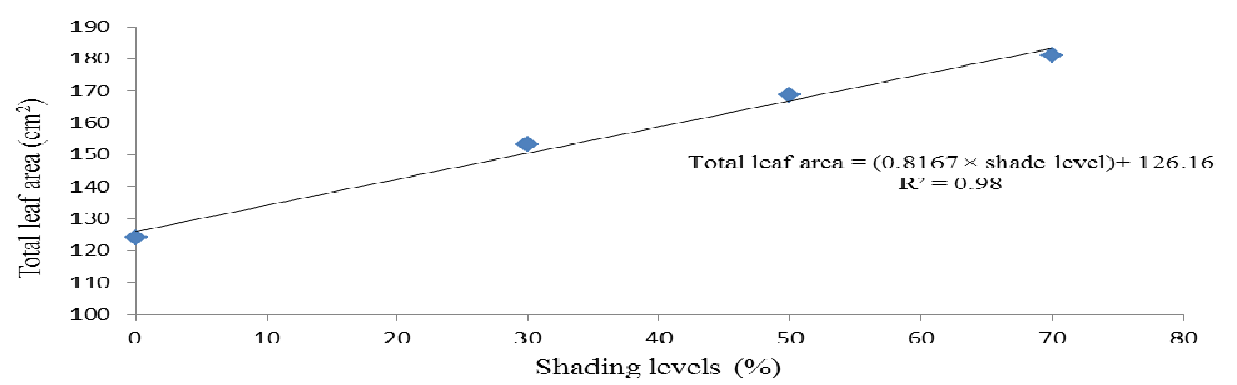

Fig.3. Linear equation for correlation between shading level and total leaf area. 


\subsection{Number of leaves}

Table 3shows a significant effect of the shading on the number of leaves, where the $70 \%$ shading levelresulted in higher number of leaves compared to the control treatment.However, there was no significant difference between $30 \%$ and $50 \%$ shading level with the control treatment.Apositive correlation was found between the shading levelsand the number of leaves, as per Figure 4,this increment in leaf number was a result in increasing of seedling height, as detailed in correlation coefficient $=0.768$ for positive correlation between leaf number and plant height, as per Table 3.The seedling increases its height, leaf area, crown extension, and leaf arrangement in order to maximize its exposure to light, which agrees with $^{[18]}$ and ${ }^{[13]}$, but not with ${ }^{[2]}$ whom found thatnumber of leaves decreased as a result of light intensity decrease.

Table 3 Leaf number as affected by different shading levels and correlation coefficient with seedling height

\begin{tabular}{|lcccc|}
\hline \multicolumn{1}{|c}{ Shading levels } & Control & $\mathbf{3 0} \%$ & $\mathbf{5 0 \%}$ & $\mathbf{7 0 \%}$ \\
\hline Leaf number & $4.12 \mathrm{~b}$ & $4.12 \mathrm{~b}$ & $4.18 \mathrm{ab}$ & $4.5 \mathrm{a}$ \\
Seedling height $(\mathrm{mm})$ & $48.55 \mathrm{~d}$ & $67.07 \mathrm{c}$ & $75.35 \mathrm{~b}$ & $85.28 \mathrm{a}$ \\
Correlation coefficient $=0.768$ & & & & \\
\hline
\end{tabular}

(Treatments with same letter are not significantly different according to Duncan test at $\mathrm{P} \leq 0.05$ ).

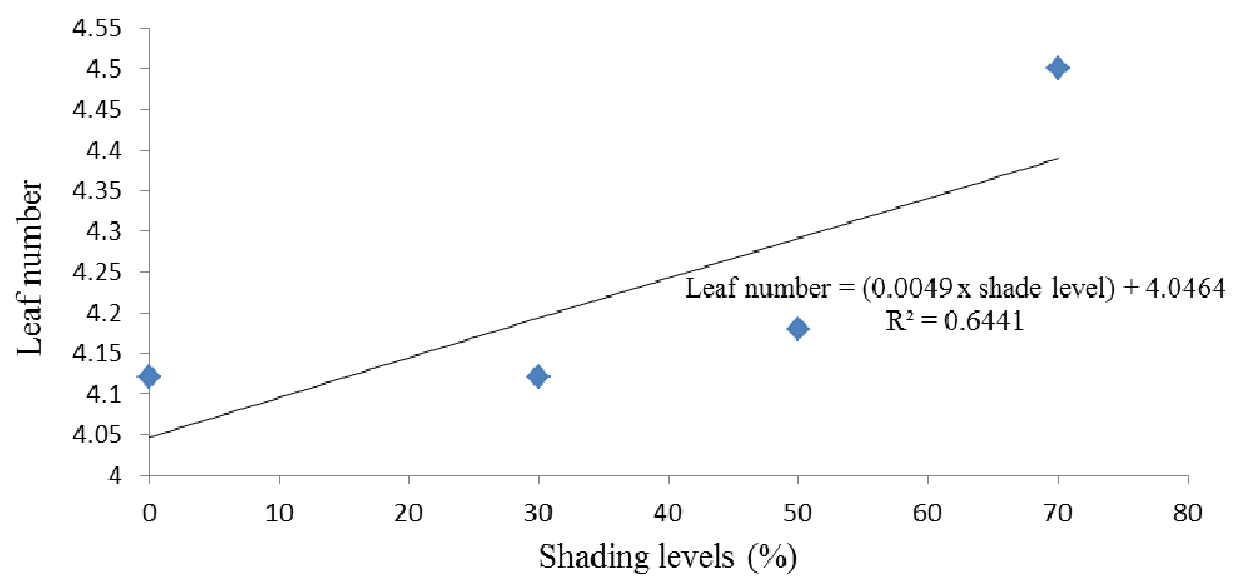

Fig.4. Linear equation for correlation between shading level and leaf number.

\subsection{Height of seedlings}

There wasa positive correlation between the shading level and seedling height (seedling height $=0.5196 \times($ shade level $\left.)+49.579\left[\mathrm{R}^{2}=0.9929\right]\right)$ based on the results shown in Figure 5. The level of shade had a significant effect on the seedling height (Table 4). The tallest seedlings were the ones under $70 \%$ shade level, while the shortest were those of the control treatment. Despite the positive correlation between seedling height with wet weight of seedling, as per correlation coefficient $=0.906$, but there was a negative correlation between the seedling height and stem diameter, as per thecorrelation coefficient $=-0.91$ (Table 4).This increment in seedling height could be attributed to the fact that seedlings increased its elongation to maximize its exposure to light in a dim environment, as per the explanations detailed in ${ }^{[7],[18]}$ and $^{[13]}$. But this disagrees with ${ }^{[2]}$ whom found reduction in seedling heights resulting to low light intensity. 
Table 4Seedling height as affected by different shading levels and correlation coefficient with wet weight of seedling and with stem diameter

\begin{tabular}{|lcccc|}
\hline \multicolumn{1}{|c}{ Shading levels } & Control & $\mathbf{3 0} \%$ & $\mathbf{5 0 \%}$ & $\mathbf{7 0 \%}$ \\
\hline Seedling height $(\mathrm{mm})$ & $48.55 \mathrm{~d}$ & $67.07 \mathrm{c}$ & $75.35 \mathrm{~b}$ & $85.28 \mathrm{a}$ \\
Wet weight of seedling $(\mathrm{g})$ & $1.17 \mathrm{~b}$ & $1.27 \mathrm{ab}$ & $1.42 \mathrm{a}$ & $1.38 \mathrm{a}$ \\
Stem diameter $(\mathrm{mm})$ & $2.23 \mathrm{a}$ & $2.21 \mathrm{a}$ & $2.09 \mathrm{~b}$ & $2.02 \mathrm{~b}$ \\
Correlation coefficient between seedling height and wet weight of seedling $=0.906$ & \\
Correlation coefficient between seedling height and stem diameter $=0.91$ & &
\end{tabular}

(Treatments with same letter are not significantly different according to Duncan test at $\mathrm{P} \leq 0.05$ ).

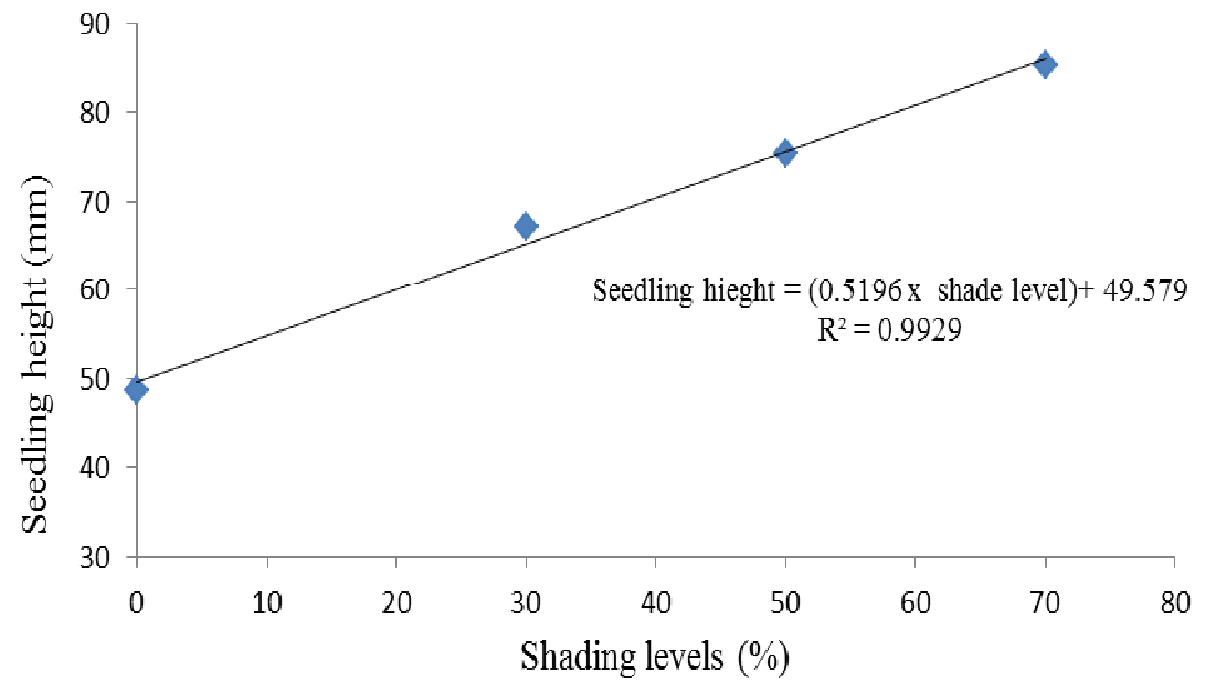

Fig.5. Linear equation for correlation between shading level and seedling height.

\subsection{Wet weight of seedlings}

The results showed a positive correlation between the seedling wet weight and the level of shade (Figure 6). Table 5shows the significant influence of the $50 \%$ and $70 \%$ shading levels on seedling wet weight compared to the control treatment. However, there was no significant difference between the $30 \%$ shading level with other shading treatments.This increment of wet weight of seedling was a result of increasing in seedling height, total leaf area, as per correlation coefficient 0.906 and 0.927 for the positive correlation between seedlings wet weight with seedling height (Table 4)and between the seedling wet weight with the total leaf area(Table 5), respectively. It could also be due to the increase in the water content of the leaf, as explained in a negative correlation between the seedling weight and the percentage of dry matter, as per correlation coefficient $=-0.957$ as explained in Table 5. The reported results could be linked to the decrease of seedling evapotranspiration under shade treatments compared to the seedling under no shade, which enhanced photosynthesis and respiration from the favorable micro-climatic conditions under the shades ${ }^{[13]}$. 
Table 5Wet weight of seedling as affected by different shading levels and correlation coefficient with seedling height, Total leaf area and with percentage of dry matter

\begin{tabular}{|lcccc|}
\hline \multicolumn{1}{|c}{ Shading levels } & Control & $\mathbf{3 0} \%$ & $\mathbf{5 0 \%}$ & $\mathbf{7 0 \%}$ \\
\hline Wet weight of seedling $(\mathrm{g})$ & $1.17 \mathrm{~b}$ & $1.27 \mathrm{ab}$ & $1.42 \mathrm{a}$ & $1.38 \mathrm{a}$ \\
Total leaf area $\left(\mathrm{cm}^{2}\right)$ & $124.22 \mathrm{c}$ & $153.25 \mathrm{~b}$ & $168.6 \mathrm{ab}$ & $181.07 \mathrm{a}$ \\
\hline Percentage of dry matter $(\%)$ & $18.73 \mathrm{a}$ & $17.12 \mathrm{~b}$ & $14.72 \mathrm{c}$ & $13.98 \mathrm{c}$ \\
Correlation coefficient between wet weight of seedling and total leaf area $=0.927$ & \\
Correlation coefficient between wet weight of seedling and Percentage of dry matter $=0.957$ & \\
\hline
\end{tabular}

(Treatments with same letter are not significantly different according to Duncan test at $\mathrm{P} \leq 0.05$ ).

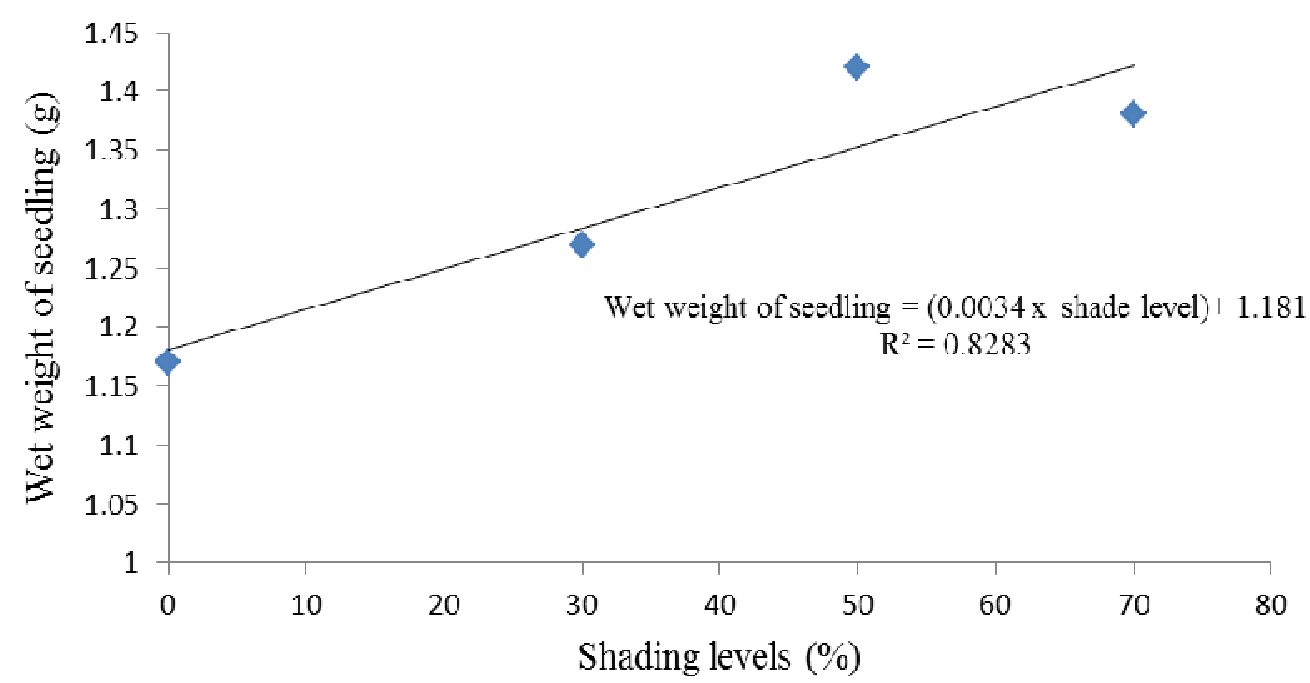

Fig.6. Linear equation for correlation between shade level and wet weight of seedlings.

\subsection{Chlorophyll Content}

The control treatment reported higher chlorophyll contentcompared to the treated samples (Table 6). Figure 7 shows the inverse relationship between chlorophyll content and shading level, where the $70 \%$ shading level resulted in the lowest chlorophyll content. Figure 7 shows this negative correlation from the equation, chlorophyll content $=(-0.092 \times$ shade level $\left.)+37.356\left[\mathrm{R}^{2}=0.93\right]\right)$.

This could be due to the chloroplast development in young leaves being inhibited when under shade, as per ${ }^{[16]}$, who reported that the synthesis of chlorophyll and the development of chloroplast are inhibited by low levels of light in young leaves, while in mature and old leaves, the chlorophyll content was higher when exposed to lower light compared to optimal light. Leaves being exposed to the sun are thicker, and is therefore expected to have more chlorophyll as opposed to the shaded leaves as showed in the negative correlation between chlorophyll content and total leaf area according to correlation coefficient $=-0.96$ (Table 6). These results agree with ${ }^{[11]}$.However, other studies reported that radiation could alter the arrangement of chloroplasts within plant cells, which could affect the chlorophyll contents. ${ }^{[6]}$ reported an increase in the amount of the SPAD value due to increased light intensity. These results, however, disagreed with the ones reported by ${ }^{[7]}$ and ${ }^{[18]}$, both of themfound increased levels of chlorophyll in samples under shade. 
Table 6Chlorophyll content as affected by different shading levels and correlation coefficient with total leaf area

\begin{tabular}{|lcccc|}
\hline \multicolumn{1}{|c}{ Shading levels } & Control & $\mathbf{3 0} \%$ & $\mathbf{5 0 \%}$ & $\mathbf{7 0 \%}$ \\
\hline Chlorophyll content (SPAD) & $37.6 \mathrm{a}$ & $33.72 \mathrm{~b}$ & $33.65 \mathrm{~b}$ & $30.65 \mathrm{c}$ \\
Total leaf area $\left(\mathrm{cm}^{2}\right)$ & $124.22 \mathrm{c}$ & $153.25 \mathrm{~b}$ & $168.6 \mathrm{ab}$ & $181.07 \mathrm{a}$ \\
Correlation coefficient $=-0.96$ & & & & \\
\hline
\end{tabular}

(Treatments with same letter are not significantly different according to Duncan test at $\mathrm{P} \leq 0.05$ ).

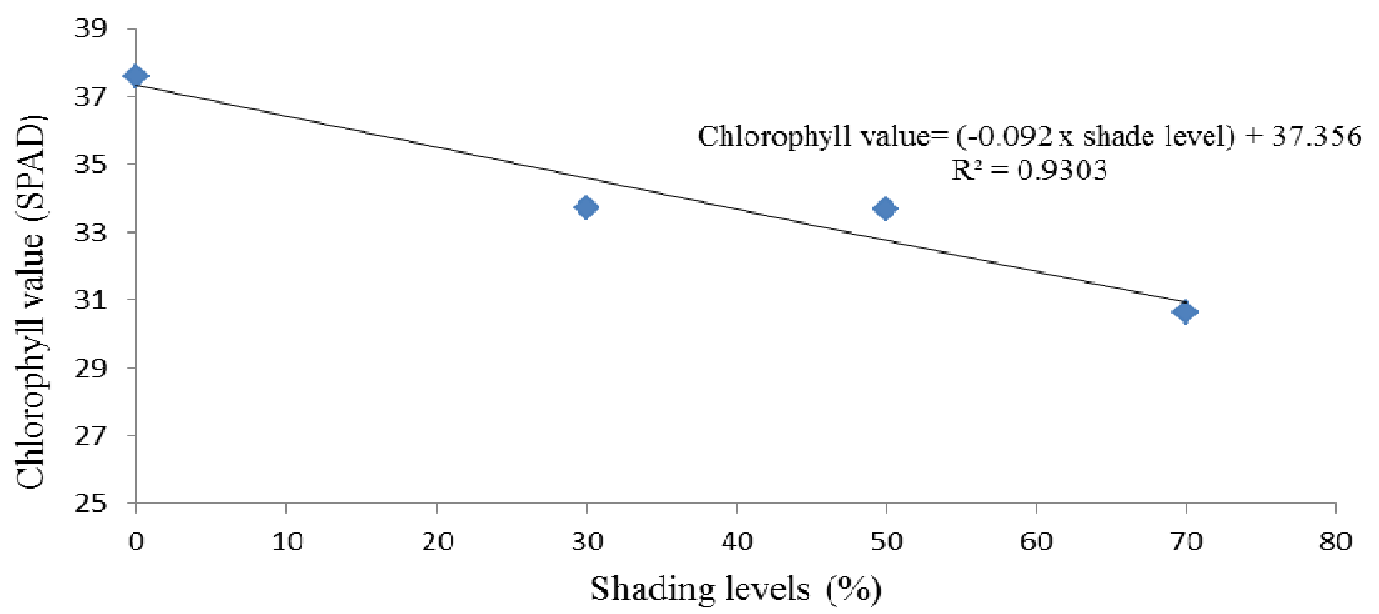

Fig.7. Linear equation for correlation between shade level and chlorophyll content.

\subsection{Stem diameter}

Figure 8bshows an inverse relationship between stem diameter and shading levels. The $70 \%$ shading levelreported the lowest stem diameter, while the control sample reported the highest stem diameter (Figure 8a).There was no significant difference between $70 \%$ and $50 \%$ shading levels, and also between $30 \%$ shading level with the control treatment. Thisis consistent with ${ }^{[7]}$ and ${ }^{[8]}$ in their study of two soybeans (Glycine max L.) cultivars, where they observed that when the light intensity was increased from 2000 to 8000 lux, the stem diameterincreased for the 032 plant cultivarsbut not for the BPplant cultivars.This seems to imply that the response of stem diameter to light is dominated by its genetic predisposition.

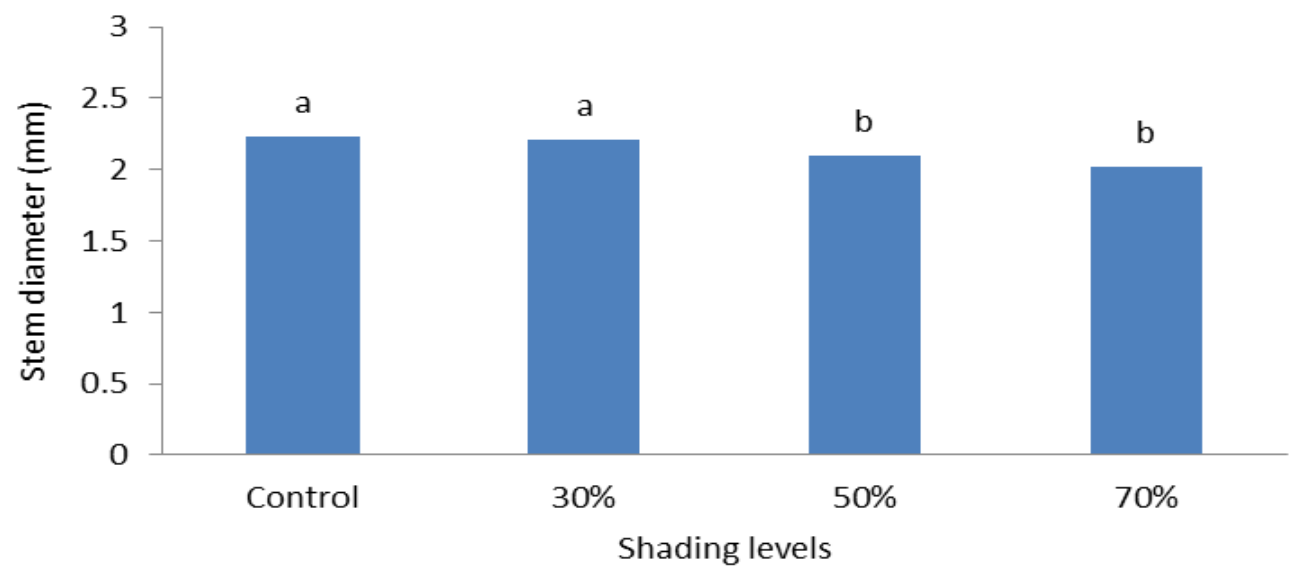

Fig.8a. Stem diameter content as affected by different shading levels 
(Treatments with same letter are not significantly different according to Duncan test at $\mathrm{P} \leq 0.05$ ).

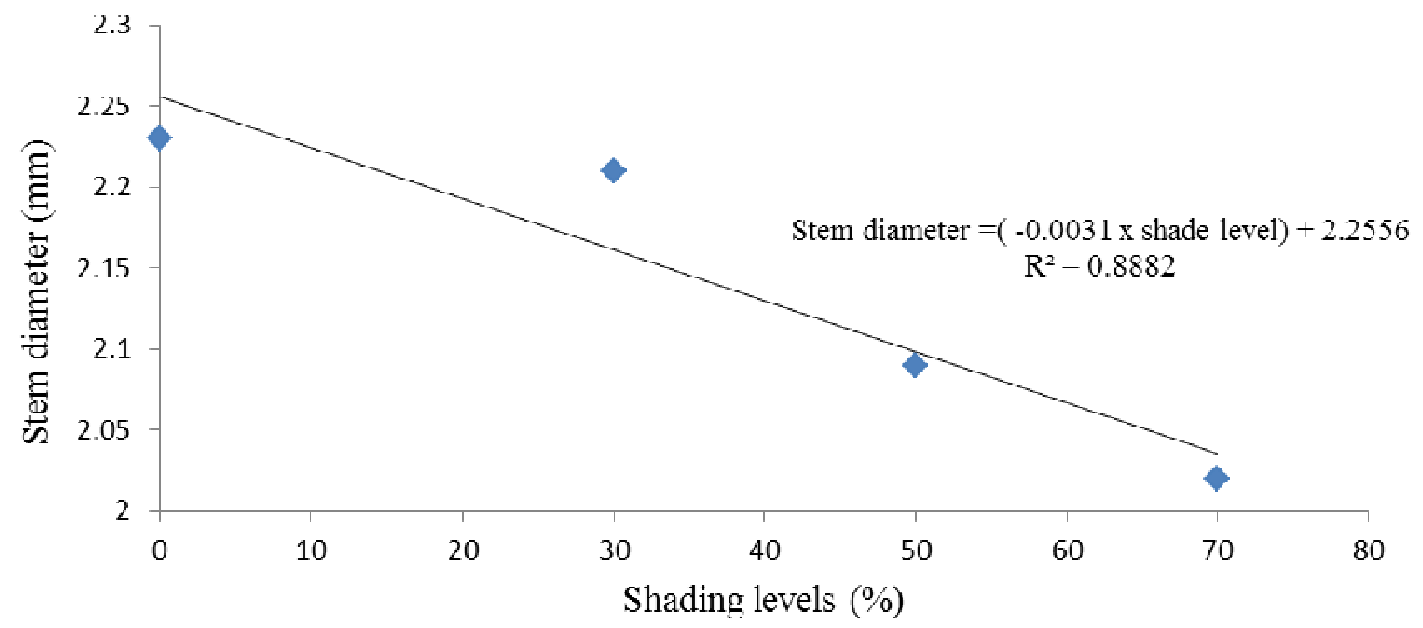

Fig.8b. Linear equation for correlation between shading level and stem diameter.

\subsection{Percentage of dry matter}

Thepercentage of dry matter of seedlings decreased with increasing levels of shading, as shown in Table andFigure9a. The control treatment reported thehighest percentage of dry matter. The percentage of dry matter of the seedlings did not differ much between $50 \%$ and $70 \%$ shading levels. This linear equation (The percentage of dry matter $=(-0.0719 \times$ shading level $\left.+18.835\left[\mathrm{R}^{2}=0.9646\right]\right)$ clarified the negative correlation between shading levels and percentage of dry matter, as perFigure 9b.This could be due to the fact that the leaves, under a full sun, have an evapotranspiration rate that exceeds those of the shaded leaves. Direct sunlight exposure could potentially damage the surface of the leaves.This prompt the plants to increase the evapotranspiration rate in order to decrease damages induced by sunlight as opposed to its shaded counterparts, which do not need to do so, as $\operatorname{per}^{[1]}$.

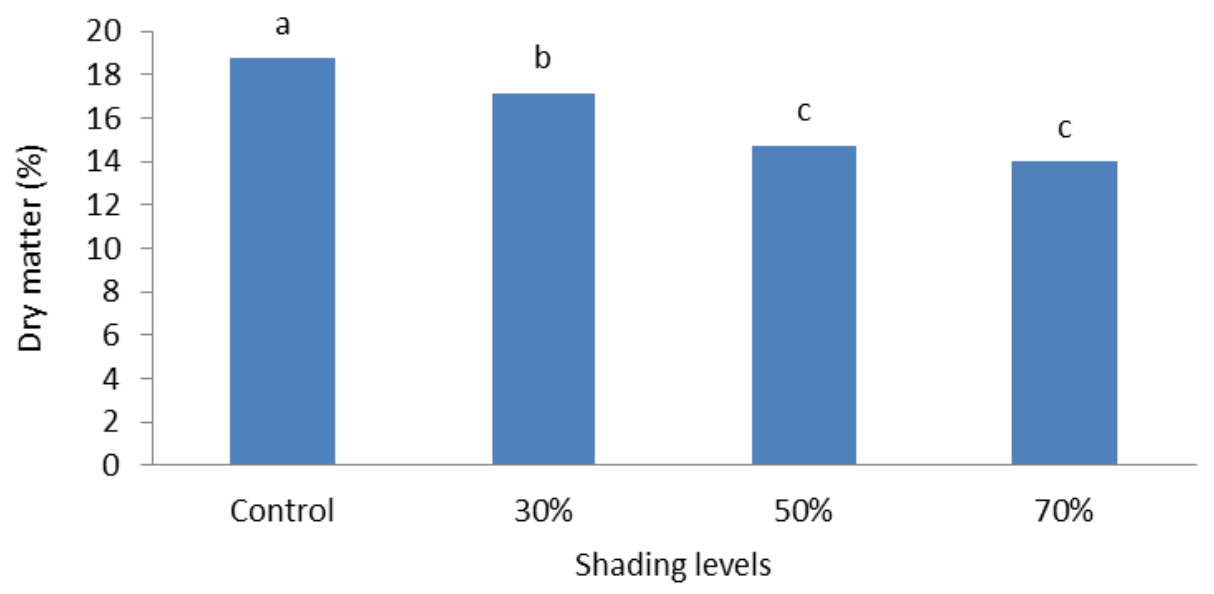

Fig.9a. Percentage of dry matter as affected by different shading levels.

(Treatments with same letter are not significantly different according to Duncan test at $\mathrm{P} \leq 0.05$ ). 


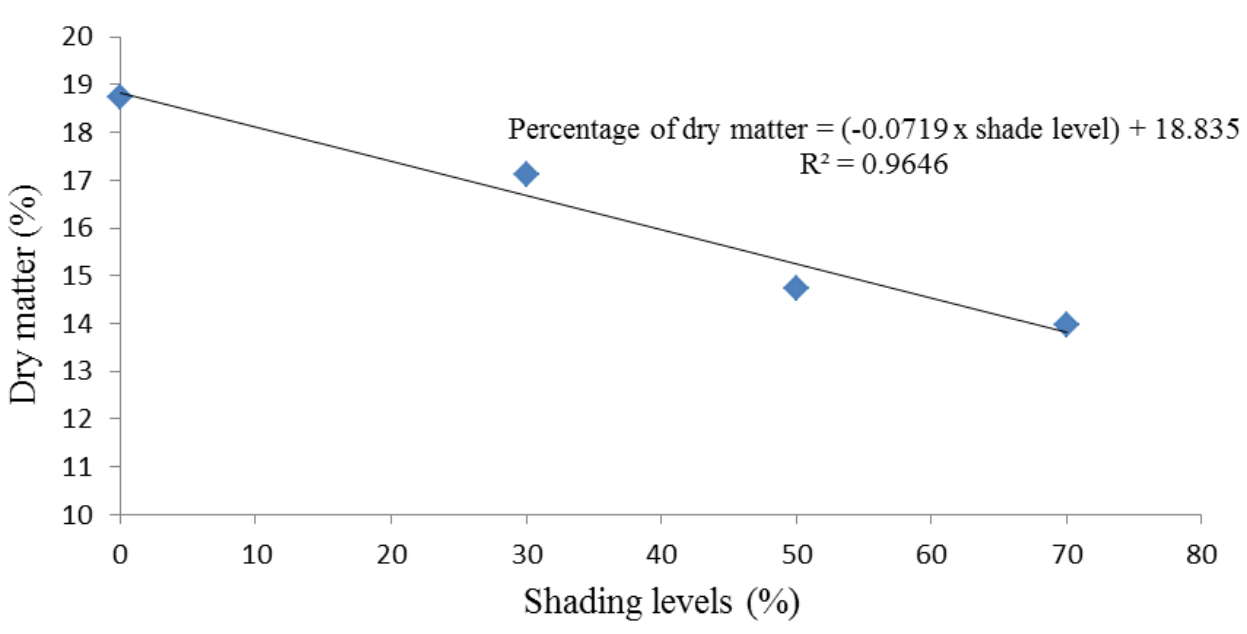

Fig.9b. Linear equation for correlation between shade level andpercentage of dry matter.

\section{CONCLUSION}

Shade treatment led to significant alterations in plant traits, despite the negative correlation between shade levels and chlorophyll content, stem diameter and percentage of dry matter. There werepositive correlations between shade levels and total leaf area, leaf number, seedlings height and seedlings weight, which were indicative of the fact that the eggplant

\section{REFERENCES}

1. Argus, Control Systems Ltd. (2010). Light and lighting control in greenhouses. Argus control systems. 1281 Johnston Road.White Rock, British Columbia. Canada.

2. Bamigboye, T.O and Kayode, J. (2016). Effect of Light Intensity on the Growth of DioscoreophyllumCumminsii. International Journal of biological papers, 1(1) : 36-40.

3. Costa, E., Durante, L. G. Y., Santos, A. D., \& Ferreira, C. R. (2013). Production of eggplant from seedlings produced in different environments, containers and substrates. HorticulturaBrasileira, 31(1), 139146.

4. Edalatifard, L., Modarres-Sanavy, S. A. M., \&Askari, H. (2014). The optimum condition under light and media for seed germination of Withaniacoagulans. International Journal of Farming and Allied Sciences, 3(7), 722-728.

5. Gairola, K. C., Nautiyal, A. R., \&Dwivedi, A. K. (2011). Effect of temperatures and germination media on seed germination of Jatrophacurcas Linn. Adv. Biores, 2(2), 6671. seedlingswereable to cope with low light environment. The shade treatmentprovided a good environment for seedling growth compared to its no shade counterpart. Furthermore, according to the experimental results, eggplant seed germination and MGT were unaffected by light intensity.

6. Goldani M, NassiriMahallati M. (2011). Impact on the quantity and quality of some morphological and physiological traits of maize (Zea mays L.) cultivars under greenhouse conditions. Journal of Agroecology 3(2), 172-180.

7. Huang, C. J., Wei, G., Jie, Y. C., Xu, J. J., Anjum, S. A., \&Tanveer, M. (2016). Effect of shade on plant traits, gas exchange and chlorophyll content in four ramie cultivars. Photosynthetica1-6, 54 (3): 390395.

8. Jenabiyan, M., Pirdashti, H., \&Yaghoubian, Y. (2014). The combined effect of cold and light intensity stress on some morphological and physiological parameters in two soybean (Glycine $\max$ L.) cultivars. International Journal of Biosciences. 5(3)189-197.

9. Koo, H. J., Park, S. M., Kim, K. P., Suh, M. C., Lee, M. O., Lee, S. K.,\& Hong, C. B. (2015). Small heat shock proteins can release light dependence of tobacco seed during germination. Plant physiology, 167(3), 10301038 . 
10. Leal, C. C., Torres, S. B., de Freitas, R. M., Nogueira, N. W., \&Farias, R. M. D. (2015). Light intensity and type of container on producing Cassia grandis L. seedlings. RevistaBrasileira de EngenhariaAgrícola e Ambiental, 19(10), 939-945.

11. Lichtenthaler, H. K., Babani, F., \&Langsdorf, G. (2007). Chlorophyll fluorescence imaging of photosynthetic activity in sun and shade leaves of trees. Photosynthesis Research, 93(1-3), 235-244.

12. Nurullzzah, A., Abdullah, A., Abdullah, M. P., Lee, Y. H., Wan Rozita, W. M., \& Fatimah, S. (2012). Patterns of fruits and vegetable consumption among adults of different ethnics in Selangor, Malaysia. International Food Research Journal, 19(3), 1095-1107.

13. Rajasekar, M., Arumugam, T., \& Kumar, S. R. (2013). Influence of weather and growing environment on vegetable growth and yield. Journal of Horticulture and Forestry, 5(10), 160-167.
14. Ranil, R. H. G., Niran, H. M. L., Plazas, M., Fonseka, R. M., Fonseka, H. H., Vilanova, S., \&Prohens, J. (2015). Improving seed germination of the eggplant rootstock Solanumtorvum by testing multiple factors using an orthogonal array design. ScientiaHorticulturae, 193, 174-181.

15. Sas Institute. (2009). SAS Scoring Accelerator 1.5 for Teradata: User's Guide. SAS institute.

16. Sui, X. L., Mao, S. L., Wang, L. H., Zhang, B. X., \& Zhang, Z. X. (2012). Effect of low light on the characteristics of photosynthesis and chlorophyll a fluorescence during leaf development of sweet pepper. Journal of Integrative Agriculture, 11(10), 1633-1643.

17. Torres, A. P., \& Lopez, R. G. (2010). Measuring daily light integral in a greenhouse. Purdue University, 1-888.

18. Ulqodry, T. Z., Matsumoto, F., Okimoto, Y., Nose, A., \&Zheng, S. H. (2014). Study on photosynthetic responses and chlorophyll fluorescence in Rhizophoramucronata seedlings under shade regimes. Actaphysiologiaeplantarum, 36(7), 1903-1917. 